\title{
Labor market of the Republic of Kazakhstan: Transformation Stages and Current State
}

\author{
Gulshat Mussayeva ${ }^{1},{ }^{*}$ Nina Vishnevskaya ${ }^{2}$ \\ ${ }^{1}$ Kyzylorda University named after Korkyt Ata, Kyzylorda, Kazakhstan \\ ${ }^{2}$ Bashkir State University, Ufa, Bashkortstan \\ *Email: m.gulshat_kz@mail.ru
}

\begin{abstract}
Relevance of the research topic. New economic challenges pose severe problems in the field of employment: the world's economies face such acute problems as growing unemployment and declining employment due to the COVID-19 epidemic. According to the ILO, the economic and labor crisis caused by the pandemic can increase global unemployment to 24.7 million people; for comparison: the global financial crisis of 2008 - 2009 increased global unemployment to 22 million people. The pandemic has accelerated the process of digitalisation, resulting in new forms and types of employment appearing, which generates reforms in the economic, social and political spheres.

The key problems in the field of employment in Kazakhstan continue to be: intersectoral movement of labor due to structural changes in the economy; high level of self-employed in rural areas; changes in labor relations due to the emergence of new types and forms of employment that conflict with current legislation and increase the risks of social insecurity of workers; disproportions in the professional and qualification structure of employment due to the imbalance between the nomenclature of training specialists in educational institutions and their use in practice; weak mobility of labor resources and inefficiency of state employment programs.

The peculiarity of the functioning of the labor market in Kazakhstan is a high level of employment and low unemployment with an imbalance in the supply and demand of labor.

The study aims to identify the main trends in the labor market transformation in Kazakhstan.

The research aims to study the theoretical foundations and practical issues of the formation and development of the Kazakh labor market. The article talks about the ongoing changes in the economy and the labor market, including under the influence of the COVID-19 pandemic, state support in employment, and identifies critical factors for the future competitiveness of the national labor market.

The object of the study is the labor market of the Republic of Kazakhstan in the context of the transformation of the national economy.

The subject of the study is the trends in employment and processes in the labor sphere of Kazakhstan, as well as the policy of stimulating employment and regulating the labor market in the conditions of economic transformation and integration processes.
\end{abstract}

Keywords: Labor market transformation, Employment transformation, Kazakhstan labor market, Employment sphere, Digital economy.

\section{INTRODUCTION}

Today, the global economy is experiencing the consequences of the negative impact of the pandemic on all spheres of economic and social life. Severe shocks have affected domestic supply and demand, trade and finance, and a decline in economic activity in advanced economies in 2020 is expected to reach $7 \%$ [1]. The crisis caused by the COVID-19 epidemic turned out to be the second-largest crisis in the history of independent Kazakhstan. 
The world experienced the last deep recession of the economy in 2009 when world GDP declined by $2.3 \%$ [2] due to the financial and economic crisis. However, it is not comparable with the consequences that arose due to the outbreak of coronavirus, as a result of which the global economy declined by $-3.5 \%$ in 2020 , according to the World Bank, the IMF - 3.2\% [3] in Kazakhstan -2.5\% [4]. Due to the negative impact on employment and income, the poverty rate increased to $14 \%$ in 2020 [5]. About $94 \%$ of all employed people on the planet somehow faced restrictive measures. The amount of time worked decreased globally by $8.8 \%$, which means the loss of 303 million full-time jobs; in Kazakhstan - 11\% or 939.2 thousand jobs [6, p. 33]

In 2020, the overall level of labor force participation under the influence of the pandemic and quarantine decreased by $0.4 \%$, the coefficient of economic activity from $70.1 \%$ to $69.2 \%$, and the number of temporarily unemployed increased by 4 times [6, p. 33]. In the annual global competitiveness index compiled by the WEF, Kazakhstan ranked 55th out of 141 countries [7]. In terms of employment, the 43rd place $(65.6 \%)$ [8]. If one operating SME creates an average of 7 jobs in the OECD countries, then we have only 2.5 jobs [6, p. 33].

\section{STUDY RESULTS}

The scientific study result is the systematisation of the transformation stages of the labor market of Kazakhstan in the process of evolution and at present. These include:

Stage I: 1991-1998 - transformation in a transitional economy;

Stage II: 1999-2008 - transformation in the conditions of economic recovery and growth;

Stage III: 2009-2019 - transformation in the conditions of economic recession;

Stage IV: 2020 - transformation in the conditions of the economic crisis caused by the deterioration of the epidemiological situation in the world (the spread of the COVID-19 epidemic).

A comparative analysis of the situation in the labor markets of Kazakhstan and foreign countries is carried out. It is revealed that the current global trends leading to changes in the labor market are also relevant for Kazakhstan, although there are national peculiarities. In the conditions of the new reality, 1 out of 5 employees around the world in 2020 was forced to work at home, and in the EU countries, $40 \%$ switched to "remote", in Kazakhstan $50 \%$ of employees [6, p. 25]. In this regard, amendments were made to the Labor Code in 2020 (Article 138) to improve the regulation and rights of employees with a remote work format.

Thanks to the anti-crisis measures taken, which amounted to $9 \%$ of GDP [6, p. 49], it was possible to maintain the unemployment rate at $4.9 \%$, which increased by only 0.1 percentage points. This is also explained by the fact that some of the employed moved into the category of "temporarily unemployed"; thus, persons who were forced not to work during the lockdown period were considered not unemployed but temporarily unemployed as part of the employed population.

Like all countries of the world, Kazakhstan is on the path to recovery from the consequences of the corona pandemic. Leading international organisations to predict steady economic growth at the level of 3.5-4\% in 2022.

\section{RESULTS ANALYSIS AND DISCUSSION}

The labor market of Kazakhstan has undergone many changes during transformation. Let's highlight the main stages of the labor market development.

Stage I: 1991-1998 - a period of radical market reforms, accompanied by a significant decrease in the number of employed people and cardinal shifts in its structure. The key factor that influenced the transformation of the labor market and employment is the privatisation and corporatisation of state-owned enterprises, which caused a catastrophic reduction in production volumes and the subsequent release of labor. The transformation of the economy from planned to market was accompanied by a disproportion within the main economic sectors. The adopted first Law "On Employment of the population" [9], was market-oriented and subsequently became a model for many CIS countries (Russia, Azerbaijan, Moldova, Ukraine). At that time, state authorities were concerned about the construction of the state, the formation of legislation and the economy as a whole, and millions of people earning a living by "shuttle" trade, fattening and selling livestock, repairs and low-skilled services, actually fell out of the state field of regulation, made up a significant part of the shadow economy of Kazakhstan [10]. At this stage, the state authorities did not apply strict measures of legislative regulation concerning self-earning people since they, at least, provided themselves with work [11].

The problem of employment and ensuring the labor market balance was proposed to be solved through the labor Exchange, which was created according to the classical model and consisted of a combination of two institutions: the State Employment Service and the Employment Promotion Fund. Coordination of the situation on the labor market was carried out from a single centre. The situation in the labor market was determined by: the continuing decline in production, unstable financial and credit system, the increase in the crisis of non-payments; regressive structural changes in employment; a decrease in the standard of living of the population, an increase in unemployment. In the period 1992-1995, real GDP fell by about 31\%, inflation 
reached three- and four-digit levels (annual consumer price inflation did not fall below 100\% until 1996); 1.6 million jobs were eliminated in the labor market, the number of employees decreased by about $30 \%$, and the number of unemployed in 1994 exceeded 1.5 million people for the first time. Kazakhstan has moved into the category of countries with high unemployment. The main area of employment for the released workers was a small business, which gradually formed the basis for expanding the service sector. For the first time, entrepreneurial activity was reflected in the Law of the Kazakh SSR "On Freedom of economic activity and development of entrepreneurship in the Kazakh SSR" [12], further in the Law of the Republic of Kazakhstan "On Protection and support of private Entrepreneurship" [13]. If in 1993 the number of private enterprises amounted to 15.7 thousand with a total of 164 thousand people employed, then in 1997 their number reached 307 thousand enterprises with 1.2 million people. Of the three main areas, commerce has come to the fore. In subsequent years, a new impetus to the development of entrepreneurship was given by the decrees of the President of the Republic of Kazakhstan [14]. Under the decree, the first special state body for small business development in Kazakhstan was created the Agency for the Support of Small Entrepreneurship within the Ministry of Economic and Trade. However, despite the government's efforts, the sphere of small business is far from perfect.

Stage II: 1999-2008 The period of recovery growth, when the level of employment increased slightly, while the intensity of structural shifts slowed down somewhat. In 1999 the labor Exchange was liquidated, the unemployed stopped receiving material support from the state in the form of unemployment benefits, there was a peak in unemployment - it amounted to a record $13.5 \%$. In addition, the labor market has become decentralised and poorly coordinated. Adopted in 1999, the new Law "On labor in the Republic of Kazakhstan" [15] marked the beginning of market regulation of labor relations in the Republic of Kazakhstan. In order to develop and encourage entrepreneurship, the law has given employers greater rights. The country has emerged from a deep socio-economic crisis associated with the collapse of the USSR and the transition from a planned economy to a market economy. In 2001-2002 Kazakhstan was (first among the CIS countries) recognised by the European Union and then by the USA as a country with a market economy. This stage relates to the adoption of the new Law of the Republic of Kazakhstan, "On Employment of the population" [16] and the "Labor Code" [17]. The global financial and economic crisis of 2007-2008 had a significant impact on the country's economy; this is due to its dependence on the external environment, namely oil and metal prices. In 2006-2008, the share of the informal sector in total employment averaged $40.6 \%$ per year (in $2005-42.9 \%$ ), and the unemployment rate was $7.3 \%$.
Stage III: 2009-2019 The period of a significant slowdown in economic dynamics and a certain stabilisation of the overall level of employment, primarily due to reasons related to the dynamics of demographic indicators. The number of people who tried to organise their own business compared to 2009 decreased sharply: in 2010 by $32.2 \%$, in 2012 by $87.9 \%$. In 2011, the "Employment 2020 Program" came into force (later, the "Employment Roadmap 2020" [18]. The following main signs characterise the state of the labor market: the growing gap between the supply and demand of skilled labor; the aggravation of the problems of employment of certain socio-demographic groups of the population: youth, disabled people, women, retired military personnel, etc.; the preservation of significant hidden unemployment in the workplace, the expansion of the supply of labor in the "shadow" employment; the direction of large flows of labor migration from the CIS states (primarily from Kyrgyzstan and Uzbekistan). Weak coordination of the labor market by the state. With the creation of the EAEU (2014), new opportunities have appeared for the participating countries related to the free choice of directions for labor relocation. The development of ICT allows you to expand the possibilities of remote work. There is an evolution of the professional and qualification structure of the workforce.

Stage IV: from 2020 to ... The period of the spread of the global epidemic "COVID-19". Since the beginning of the year, the national economy has been developing in a difficult situation; Kazakhstan's GDP in the first half of 2020 decreased by $1.8 \%$, the service sector by $5.6 \%$ [19]. More than half of the companies, including the education sector, have entirely switched to remote work. Small businesses, especially the service sector: tourism and restaurants, airlines, etc., suffer losses. Those who have implemented digital technologies less than others will suffer. The Government is taking "Anti-crisis measures" [20] to support the unemployed, socially vulnerable groups of the population and small businesses; funds have been allocated from the National Fund. The State Enterprise "Employment Roadmap 2025" has been developed [21], which will provide jobs for 250 thousand unemployed, 130 thousand jobs have been created within 6.5 thousand projects, $35 \%$ of them are young people.

The global unemployment rate rose to $6.5 \%$ in 2020 compared to $5.4 \%$ in 2018-2019. According to the official data of the Ministry of National Economy of the Republic of Kazakhstan, the unemployment rate increased by only 0.1 percentage points to $4.9 \%$, and the total number of unemployed is 500 thousand people; however, economists [22] cite a figure of at least 2 million people, and the "ER" is designed only for every 10th unemployed. Only 100-150 people applied to the capital's employment centre before quarantine per day, now twice as many. Many worked in the service sector. Due to the coronavirus, almost $50 \%$ of the employed lost their primary earnings. So far, it is impossible to 
accurately assess the extent of the effects and consequences of COVID-19 on employment. Significant changes are expected at the global level. The pandemic will accelerate Industry 4.0, leading to the digitalisation of economies. This issue is the subject of study by foreign and domestic scientists.

The impact of the active use of digital technologies on the labor market is considered in the works of Harald Kaiser, Peter Gerdemann et al. [23]. The article by M. Lucchese, M. Pianta examines the impact of the coronavirus pandemic on the economy, examines the economic consequences in conditions of financial instability, economic recession, declining incomes and political problems [24].

A.J. Brown, J. Kettle propose a new classification of active labor market programs depending on their goals, relevance and economic efficiency during a regular time, crisis and economic recovery [25]. Quarantine measures continue to affect the labor market.

In 2020, the restrictive measures taken in connection with the COVID-19 pandemic had a significant impact on the state of the EAEU labor market. Against this background, the EAEU noted a decrease in the number of the labor force and the employed population,

Table 1. The main indicators of the Kazakhstan labor market

\begin{tabular}{|c|c|c|c|c|c|c|c|}
\hline Indicators & 2015 & 2016 & 2017 & 2018 & 2019 & 2020 & $2021^{*}$ \\
\hline Labor force, thousand people & 8887,6 & 8998,8 & 9027,4 & 9138,6 & 9221,5 & 9180,8 & 9254,8 \\
\hline $\begin{array}{l}\text { The share of the labor force in the } \\
\text { population, \% }\end{array}$ & 71,3 & 71,3 & 71,1 & 70,0 & 69,7 & 69,2 & 69,5 \\
\hline $\begin{array}{l}\text { Employed population, thousand } \\
\text { people }\end{array}$ & 8433,3 & 8553,4 & 8585,2 & 8695,0 & 8780,8 & 8732,0 & 8804,1 \\
\hline \multicolumn{8}{|c|}{ Employment rate, as a percentage of: } \\
\hline population aged 15 years and older & 67,6 & 66,5 & 66,3 & 66,2 & 66,1 & 65,9 & 65,9 \\
\hline the number of the labor force & 95,0 & 95,0 & 95,1 & 93,2 & 93,7 & 95,1 & 95,1 \\
\hline Employees, thousand people & 6294,9 & 6342,8 & 6485,9 & 6612,5 & 6681,6 & 6686,7 & 6684,9 \\
\hline Self-employed, thousand people & 2138,4 & 2210,5 & 2099,2 & 2082,5 & 2099,2 & 2045,4 & 2119,2 \\
\hline Full employment, \% & 41 & 44 & 39 & 39 & 39 & 39 & 39 \\
\hline Temporary employment, \% & 32 & 30 & 36 & 36 & 36 & 38 & 38 \\
\hline Self-employment, \% & 27 & 26 & 25 & 25 & 25 & 25 & 25 \\
\hline $\begin{array}{l}\text { Unemployed population, thousand } \\
\text { people }\end{array}$ & 454,2 & 445,5 & 442,3 & 443,6 & 440,7 & 448,8 & 450,7 \\
\hline General unemployment rate, \% & 5,1 & 5,0 & 4,9 & 4,9 & 4,8 & 4,9 & 4,9 \\
\hline Registered unemployment rate, \% & 0,4 & 0,4 & 0,8 & 1,0 & 1,1 & 1,5 & 1,3 \\
\hline $\begin{array}{l}\text { Youth unemployment rate, \% } \\
\text { (aged } 15-24 \text { years) }\end{array}$ & 4,2 & 3,8 & 3,8 & 3,7 & 3,6 & 3,8 & 3,8 \\
\hline $\begin{array}{l}\text { Youth unemployment rate, \% } \\
\text { (aged } 15-28 \text { years) }\end{array}$ & 4,4 & 4,1 & 3,9 & 3,8 & 3,7 & 3,8 & 3,7 \\
\hline Long-term unemployment rate, \% & 2,5 & 2,2 & 2,2 & 2,2 & 2,2 & 2,2 & 2,2 \\
\hline $\begin{array}{l}\text { Average duration of } \\
\text { unemployment, months }\end{array}$ & 6,8 & 6,9 & 6,7 & 6,2 & 6,3 & 6,0 & 6,0 \\
\hline $\begin{array}{l}\text { Persons who are not included in } \\
\text { the labor force, thousand people }\end{array}$ & 3867,4 & 3855,0 & 3927,3 & 3907,3 & 3934,0 & 4076,8 & 4063,5 \\
\hline $\begin{array}{l}\text { The share of the persons who are } \\
\text { not included in the labor force in } \\
\text { the population, \% }\end{array}$ & 28,9 & 30,0 & 30,3 & 30,3 & 30,3 & 30,8 & 30,5 \\
\hline
\end{tabular}

Source: Compiled by the authors based on materials [26] *Q3 2021. 
increasing the number of unemployed and the unemployment rate. At the same time, the positive trend of nominal and real wages growth has been maintained in all Member States. At the same time, the level of labor force participation in the EAEU decreased by 0.3 percentage points and amounted to $63.0 \%$ in 2020. It was higher than in the EAEU in Belarus $(70.3 \%)$ and Kazakhstan (69.2\%) [22, p. 12].

The most significant increase in the number of unemployed was observed in Russia (by 24.7\%), in Kazakhstan by $1.9 \%$. At the same time, there was a positive trend in the number of unemployed in Armenia and Belarus (by $2.7 \%$ and $3.4 \%$, respectively). The unemployment rate in the EAEU increased by 1.0 percentage points compared to 2019 and amounted to $5.8 \%$; in Kazakhstan, it has remained at $4.9 \%$ over the last five-year period, it is evident that the real unemployment rate is much higher (Table 1). Thanks to implementing programs to stabilise the situation in the labor market, the youth unemployment rate decreased from $5.2 \%$ to $3.8 \%$ [6].

In 2020 the registered unemployment rate was $1.5 \%$, 0.4 percentage points higher than 2019 . The gap between total and registered unemployment in Kazakhstan is more than $50 \%$ in several foreign countries; on the contrary, the number of registered unemployed exceeds the statistical estimate [6, p. 79].

However, the number of unemployed in the total number of EAS in Kazakhstan is significantly higher than similar indicators in developed countries: Germany (3.4\%), Great Britain (3.7\%), USA (3.9\%) and Japan $(2.4 \%)$. At the same time, Kazakhstan maintains unemployment at a level lower than in countries such as France $(9.1 \%)$, Canada (5.8\%) and Sweden (6.4\%) [27]. It should be noted that the increase in employment is mainly due to a decrease in the unemployment rate.

The official unemployment rate in Kazakhstan for July 2021 was $4.9 \%$. At the end of July, 223.5 thousand people were registered with the employment authorities as unemployed. The share of registered unemployed was $2.4 \%$ of the workforce, $76.1 \%$ of the total number of employed were employed [28]. High unemployment and inflation are rigidity factors in the labor market, as is the minimum wage since it leaves no room for rapid adaptation to market conditions [29]. In the innovation and information economy, the intellectual capital of employees becomes multifunctional and universal; it is vital to strive for constant professional growth, focus on success, leadership qualities [30].

\section{CONCLUSIONS}

1. Kazakhstan's experience in reforming the labor market and improving employment meets the requirements of a market economy.
2. The state of the labor market and employment of the population of Kazakhstan has been significantly influenced by market factors, structural adjustment, stabilisation of economic processes, digitalisation and the pandemic.

3. The first decade of independent Kazakhstan was characterised by the absence of a modern legal framework in employment regulation, the second was characterised by its formation, and the third by its improvement.

4. The policy of maintaining a high level of employment aims to increase the productively employed population and mass entrepreneurship through developing microcredit, vocational training and improving population mobility.

\section{REFERENCES}

[1] N.E. Bondarenko, The Russian labor market in the conditions of a pandemic of a new coronavirus infection: trends, challenges and state regulation [Rossijskij rynok truda $\mathrm{v}$ usloviyah pandemii novoj koronavirusnoj infekcii: tendencii, vyzovy i gosudarstvennoe regulirovanie] // Innovations and investments [Innovacii i investicii] 7 (2020) 63-69.

[2] Analysts: It will take three to four years for the world economy to reach the pre-crisis level [Analitiki: Na dostizhenie dokrizisnogo urovnya mirovoj ekonomike potrebuetsya tri-chetyre goda] / News [Novosti] / Finance, UA. Retrieved from: https://news.finance.ua/ru/news/-/193802/analitikina-dostizhenie-dokrizisnogo-urovnya-mirovojekonomike-potrebuetsya-tri-chetyre-goda

[3] The World Bank, Prospects for the development of the world economy [Vsemirnyj bank. Perspektivy razvitiya mirovoj ekonomiki], June 2021. Retrieved from:

https://www.vsemirnyjbank.org/ru/publication/glo bal-economic-prospects

[4] World Economic Outlook [Perspektivy mirovoj ekonomiki], January 2021. Retrieved from: https://thedocs.worldbank.org/en/doc/9961115998 387319660050022020/original/GlobalEconomicProspectsJa nuary2021RegionalOverviewECARU.pdf

[5] The World Bank, Overview of Kazakhstan [Vsemirnyj bank. Obzor po Kazahstanu]. Retrieved from:

https://www.vsemirnyjbank.org/ru/country/kazakh stan/overview\#3

[6] National report "The labor market of Kazakhstan: development in a new reality" [Nacional'nyj doklad «Rynok truda Kazahstana: razvitie v usloviyah 
novoj real'nosti»], 2021. 227 p. Retrieved from: https://iac.enbek.kz/ru/node/1179

[7] Kazakhstan in the Global Competitiveness Index of the World Economic Forum [Kazahstan v Global'nom indekse konkurentosposobnosti Vsemirnogo ekonomicheskogo foruma]. Retrieved from:

/.https://www.gov.kz/memleket/entities/adiletalmaty/press/news/details/208635?lang=rul

[8] Ranking of the world's countries by the level of employment [Rejting stran mira po urovnyu zanyatosti] / Humanitarian Portal: Research [Electronic resource] [Gumanitarnyj portal: Issledovaniya [Elektronnyj resurs]] // Centre for Humanitarian Technologies [Centr gumanitarnyh tekhnologij], 2006-2021 (last edition: 11/13/2021). URL: $\quad$ https://gtmarket.ru/ratings/employmentranking

[9] The Law Kazakh SSR of December 15, 1990 "On employment of the population" [Zakon Kazahskoj SSR ot 15 dekabrya 1990 g. "O zanyatosti naseleniya"] Z902200_, (Vedomosti of the Supreme Soviet of the Kazakh SSR [Vedomosti Verhovnogo Soveta Kazahskoj SSR], 1991. Retrieved from: https://adilet.zan.kz/rus/docs/Z900002200_/links

[10] M.A. Kusainov, The role of small and mediumsized enterprises in solving regional problems of employment and unemployment [Rol' malogo i srednego predprinimatel'stva $\mathrm{V}$ reshenii regional'nyh problem zanyatosti i bezraboticy] / M.A. Kusainov / Management of economic systems [Upravlenie ekonomicheskimi sistemami], No. 37, 2012.

[11] Kazakhstan Information Portal [Electronic resource] [Kazahstanskij informacionnyj portal]. Access mode: www.nur.kz/1049829nazarbaevaprizvala - neplatelshchikov.html /

[12] The Law of the Kazakh SSR "On freedom of economic activity and development of entrepreneurship in the Kazakh SSR" [Zakon Kazahskoj SSR «O svobode hozyajstvennoj deyatel'nosti i razvitii predprinimatel'stva V Kazahskoj SSR»], Almaty, 11.12.1990.

[13] The Law of the Republic of Kazakhstan "On protection and support of private entrepreneurship" [Zakon RK «O zashchite i podderzhke chastnogo predprinimatel'stva»], Almaty, 4.07.1992.

[14] Decree of the President of the Republic of Kazakhstan dated 03/6/1997 No. 3398 "On measures to strengthen state support and enhance the development of small entrepreneurship" and dated 04/27/1998 No. 3928 "On the protection of the rights of citizens and legal entities to freedom of entrepreneurial activity" [Ukaz Prezidenta RK ot $6.03 .1997 \mathrm{~g}$. № 3398 «O merah po usileniyu gosudarstvennoj podderzhki i aktivizacii razvitiya malogo predprinimatel'stva» $\mathrm{i}$ ot $27.04 .1998 \mathrm{~g}$. № 3928 «O zashchite prav grazhdan i yuridicheskih lic na svobodu predprinimatel'skoj deyatel'nosti»].

[15] The Law of the Republic of Kazakhstan "On labor in the Republic of Kazakhstan" dated December 10, 1999, No. 493-I [Zakon RK «O trude v RK» ot 10 dekabrya 1999 goda № 493-I]. Retrieved from: https://adilet.zan.kz/rus/docs/Z990000493

[16] The Law of the Republic of Kazakhstan "On employment of the population" dated January 23, 2001, No. 149-II [Zakon RK «O zanyatosti naseleniya» ot 23 yanvarya 2001 goda №149-II]. Retrieved

from: https://online.zakon.kz/Document/?doc $\mathrm{id}=31021$ 265

[17] Labor Code of the Republic of Kazakhstan No. 251III dated May 15, 2007 [Trudovoj kodeks Respubliki Kazahstan ot 15 maya 2007 goda №251 III]. Retrieved from: https://online.zakon.kz/Document/?doc $\mathrm{id}=30103$ $\underline{567}$

[18] "Employment Roadmap 2020", Approved by orderPrime Minister of the Republic of Kazakhstan dated March 27, 2020 No. 55-R [ «Dorozhnaya karta zanyatosti-2020», Utverzhdena rasporyazheniem Prem'er-Ministra RK ot 27 marta 2020 goda № 55r]. Retrieved from: https://adilet.zan.kz/rus/docs/R2000000055

[19] Retrieved from: https://kapital.kz/economic/88449/v-i-polugodii2020-goda-ekonomika-kazakhstana-snizilas-na-18.html

[20] Anti-crisis measures of the Government: how much money will be allocated to support citizens and the economy in an emergency [Antikrizisnye mery Pravitel'stva: skol'ko sredstv budet napravleno na podderzhku grazhdan i ekonomiki v usloviyah CHP].

Source:

https://primeminister.kz/ru/news/reviews/antikrizis nye-mery-pravitelstva-skolko-sredstv-budetnapravleno-na-podderzhku-grazhdan-i-ekonomikiv-usloviyah-chp-1731059; A comprehensive plan to restore economic growth by the end of 2021 . Resolution of the Government of the Republic of Kazakhstan dated May 20, 2020, No. 307 [Kompleksnyj plan po vosstanovleniyu ekonomicheskogo rosta do konca 2021 goda. Postanovlenie Pravitel'stva Respubliki Kazahstan ot 
20 maya 2020 goda № 307]. Retrieved from: https://adilet.zan.kz/rus/docs/P2000000307

[21] "Business Roadmap 2025", Resolution of the Government of the Republic of Kazakhstan dated December 24, 2019, No. 968 ["Dorozhnaya karta biznesa-2025". Postanovlenie Pravitel'stva Respubliki Kazahstana ot 24 dekabrya 2019 goda № 968]. Retrieved from: https://adilet.zan.kz/rus/docs/P1900000968

[22] Maksat Halyk. Retrieved from: https://yandex.kz/turbo/s/zakon.kz/5025056skolko-na-samom-dele-bezrabotnyh-v.html

[23] H. Kayser et al. Accelerating labor market transformation. June 26, 2017. URL: https://www.g20insights.org/policy briefs/accelerating-labormarket-transformation /- (accessed: 04.10.2020).

[24] M. Lucchese, M. Pianta, The Coming Coronavirus Crisis: What Can We Learn? Intereconomics 55 (2020) 98-104. DOI: https://doi.org/10.1007/s10272-020-0878-0 (accessed: 03.10.2020).

[25] A.J. Brown, J. Koettl, Active labor market programs - employment gain or fiscal drain? IZA J laborEcon 4 (2015) 12. DOI: https://doi.org/10.1186/s40172015-0025-5 (accessed: 04.10.2020).

[26] The Eurasian Economic Union in numbers: a brief statistical collection; the Eurasian Economic Commission [Evrazijskij ekonomicheskij soyuz v cifrah: kratkij statisticheskij sbornik; Evrazijskaya ekonomicheskaya komissiya], Moscow, 2021, 188 p.

[27] Committee on Statistics of the Ministry of National Economy of the Republic of Kazakhstan, Main indicators of labor and employment statistics [Komitet po statistike MNE RK. Osnovnye pokazateli statistiki truda i zanyatosti] Retrieved from:

http://stat.gov.kz/official/industry/25/statistic/7

[28] The unemployment rate in some countries of the world. 1995-2018 [Uroven' bezraboticy v otdel'nyh stranah mira. 1995-2018gg] [electronic resource]. URL: http://www. stat.gov.kz

[29] A.C., Serban, M.I. Aceleanu, Minimum wage Labor market rigidity factor // Theoretical and applied economics 22-2(603) (2015) 171-182.

[30] O.V. Aleshkina The impact of intellectual capital on the region's economy [Vliyanie intellektual'nogo kapitala na ekonomiku regiona] // Economics and Management: a scientific and practical journal
[Ekonomika i upravlenie: nauchno-prakticheskij zhurnal] 1(145) (2019) 22-25. 